\title{
PENGARUH FAKTOR INTRINSIK DAN EKSTRINSIK DIMODERASI MOTIVASI KERJA TERHADAP KINERJA GURU
}

\author{
Leni Amalia Anggraeni \\ Departemen Manajemen, STIE Malangkucecwara Malang, Indonesia, \\ leni.amalianggraen1@gmail.com
}

\begin{abstract}
Background - Competent teachers can produce quality education. The problem that exists is the number of teachers in schools who lack motivation, this is due to the low enthusiasm of teachers when teaching in several schools. In addition, teacher workloads that exceed the limit and lack of training to improve teacher skills also lead to a lack of teacher motivation. The solution is the need to increase work motivation from both extrinsic and intrinsic factors.
\end{abstract}

Purpose - To find out the influence of instristic and extraneous factors moderated work motivation on teacher performance

Design/Methodology/Approach - This research method uses a causality research design. The population of the study was 86 junior high school teachers in Poncokusumo District. With the research sample 46 SMP teachers who have been certified. The approach used is quantitative with Moderated Regression Analysis (MRA).

Result and Discussion - The results of data analysis state: (1) intrinsic factors affect teacher performance, (2) extrinsic factors affect teacher performance, and (3) moderated intrinsic and extrinsic factors affect teacher performance.

Conclusion - The results of this study are the intrinsic and extrinsic factors which are moderated by motivation have a significant effect on performance. Motivation strengthens the relationship between intrinsic and external factors on teacher performance in junior high schools in Poncokusumo sub-district.

Research Implications - This research has implications for the influence of intrinsic and extrinsic factors as well as motivation as moderation on teacher performance

Keywords: Intrinsic, Extrinsic, Motivation, Teacher, Performance

\begin{abstract}
ABSTRAK
Latar Belakang - Guru yang berkompeten dapat menghasilkan pendidikan berkualitas. Permasalahan yang ada yaitu banyaknya guru di sekolah yang kurang memiliki motivasi, hal ini dikarenakan rendahnya antusias guru saat mengajar di beberapa sekolah. Selain itu beban kerja guru yang melebihi batas serta kurangnya pelatihan untuk meningkatkan skill guru juga menimbulkan kurangnya motivasi. Solusinya adalah perlunya peningkatan motivasi kerja baik dari factor ekstrinsik dan instrinsik.

Tujuan - Untuk mengetahui pengaruh factor Instristik dan Ekstrintik dimoderasi motivasi kerja terhadap kinerja guru.

Desain/ Metodologi/ Pendekatan - Metode penelitian ini menggunakan desain penelitian kausalitas. Populasi penelitian adalah guru SMP se-Kecamatan Poncokusumo berjumlah 86 guru. Dengan sampel penelitian 46 guru SMP yang sudah bersertifikasi. Pendekatan yang digunakan ialah kuantitatif dengan Moderated Regression Analysis (MRA).

Hasil dan Pembahasan - Hasil penelitian menunjukkan bahwa (1) Faktor intrinsik berpengaruh signifikan terhadap kinerja guru, (2) Faktor ekstrinsik berpengaruh signifikan terhadap kinerja guru, dan (3) Faktor intrinsik dan ekstrinsik dimoderasi motivasi kerja berpengaruh terhadap kinerja guru.

Kesimpulan - Hasil penelitian ini ialah Faktor interinsik dan faktor eksterinsik merupakan faktor yang dapat mempengaruhi kinerja serta Faktor Intrinsik dan Eksterinsik yang Dimoderasi Motivasi berpengaruh signifikan Terhadap Kinerja. Motivasi memperkuat hubungan antara faktor interinsik dan faktor eksterinsik pada kinerja guru di SMP se-kecamatan Poncokusumo.
\end{abstract}


Implikasi penelitian - Penelitian ini berimplikasi pada pengaruh dari factor Intrinsik dan Eksterinsik serta motivasi sebagai moderasi terhadap kinerja guru.

Kata Kunci: Intrinsik, Ekstrinsik, Motivasi, Kinerja, Guru

\section{PENDAHULUAN}

Pendidikan merupakan salah satu investasi terpenting yang dilakukan suatu negara untuk di masa depan (Decreuse and Granier, 2013). Adanya dukungan bagi setiap negara sangat penting untuk memastikan bahwa peserta didik mendapatkan pendidikan yang berkualitas. Pada dasarnya pendidikan dapat berkontribusi pada stabilitas sosial dan mendorong pertumbuhan ekonomi jangka panjang (Hamid. 2017).

Pembangunan pendidikan di Indonesia tertuang dalam Undang-Undang yang disebut dengan Pendidikan Nasional (PN). PN ini berdasarkan Pancasila dan UndangUndang Dasar Negara Republik Indonesia Tahun 1945 yang berakar pada nilai-nilai agama dan kebudayaan nasional Indonesia serta terhadap tuntutan perubahan zaman. PN diselenggarakan untuk menghantar bangsa Indonesia agar siap menyongsong dan menghadapi era global dan perubahan cepat. PN harus diposisikan secara tepat agar memiliki peran nyata dalam pembangunan bangsa dan negara, khususnya meningkatkan kesejahteraan masyarakat. Hal ini dapat dicapai jika kualitas SDM pendidikan khususnya guru memiliki kualitas yang disyaratkan. Guru yang demikian menurut Sedarmayanti
(2009) sebagai insan pembangunan yang berkualitas dan handal. Mengingat pentingnya PN maka kualitas guru perlu ditingkatkan melalui motivasi.

Permasalahan yang ada yaitu banyaknya guru di sekolah yang kurang memiliki motivasi, hal tersebut dibuktikan dengan kurangnya antusias guru saat mengajar di beberapa sekolah. Selain itu beban kerja guru yang melebihi batas serta kurangnya pelatihan untuk meningkatkan skill guru juga menimbulkan kurangnya motivasi guru. Solusi untuk meningkatkan motivasi dalam bentuk energi intrinsik dan ekstrinsik yaitu dengan memberikan dorongan batin bagi individu untuk berbuat sesuatu sehingga menimbulkan ketekunan. Menurut (Deci and Ryan 2008) pemberian insentif untuk merangsang tindakan dan motif individu dalam melaksanakan suatu tugas disebut sebagai motivasi. Selanjutnya suatu kegiatan individu yang berasal dari keinginan, minat dan kinerja pribadi dianggap sebagai motivasi intrinsik (Abdulrasheed et al, 2016). Motivasi guru merupakan dorongan dalam diri untuk melaksanakan Kegiatan Belajar Mengajar (KBM), memberikan arah dan tujuan pada KBM. Mulyana (2006) menyatakan guru merupakan yang memiliki peran sangat penting dalam menentukan keberhasilan 
pembelajaran, fungsi utama guru yakni merancang, mengelola, melaksanakan, dan mengevaluasi pembelajaran. Seorang Guru yang tinggi motivasinya akan melaksanakan tugasnya dengan baik. Hasil penelitian Cholil (2014) dan Mas'ud (2017) menemukan bahwa motivasi kerja berpengaruh terhadap kinerja guru. Kinerja guru dapat meningkat atau menurun yang disebabkan oleh faktor internal dan eksternal. Faktor internal merupakan faktor yang berasal dari dalam atau individu itu sendiri. Faktor ini biasanya berupa sikap juga sifat yang melekat dalam diri seseorang. Faktor eksternal merupakan faktor yang berasal dari luar diri seseorang.

Sehubungan dengan eksistensi guru di lembaga pendidikan, maka perlu diwujudkan dalam proses pembelajaran. Keberhasilan guru dalam melaksanakan mengajar/mendidik dipengaruhi oleh beberapa faktor, antara lain (1) fasilitas, (2) biaya, (3) minat, (4) sikap, serta (5) kemampuan guru itu sendiri. Hasil penelitian Muskanan (2014) menjelaskan terdapat hubungan yang sangat kuat antara faktor intrinsik dengan motivasi karyawan, lebih lanjut Hernando (2016) membuktikan bahwa Faktor-faktor tersebut diduga mempunyai pengaruh terhadap kinerja guru. Keperluan penelitian untuk menguji dan menganalisa pengaruh factor instrinsik dan ekstrinsik dimoderasi motivasi kerja terhadap kinerja guru

\section{TINJAUAN PUSTAKA}

\section{Faktor Instrinsik}

Menurut Gunarsa (2008) motivasi intrinsik merupakan dorongan atau kehendak yang kuat yang berasal dari dalam diri seseorang. Luthan (2011) faktor intrinsik adalah faktor yang mendorong seseorang untuk berprestasi yang bersumber dalam diri individu tersebut, yang lebih dikenal dengan faktor motivasional. Faktor-faktor intrinsik menurut Robbins (2006) antara lain.

\section{Kepuasan kerja}

Tingkat kepuasan setiap orang berbedabeda dan hal ini terjadi individu memiliki dimensi yang berbeda. Menurut Hasibuan (2002) dan Robbins (2006) kepuasan kerja seorang pegawai dapat dilihat dari menyenangi pekerjaannya, mencintai pekerjaanya, moral kerja positif, disiplin kerja dan prestasi kerja.

2. Tanggung jawab

Menurut Shaw (2018), Tanggung jawab ialah orang yang bertanggungjawab terhadap tindakannya serta dapat bertanggungjawab atas perbuatannya dan mengambil keputusan serta bertindak tanpa tekanan dari pihak manapun atau secara bebas. Faktorfaktor yang mempengaruhi tanggung jawab seorang Guru (professional) antara lain, tanggung jawab sosial, moral dan spiritual serta pribadi. 
3. Pengembangan profesi

Menurut Yamin (2006) dan Danim (2002) menyatakan, profesi dapat diartikan sebagai suatu pekerjaan yang mempersyaratkan pendidikan tinggi bagi pelakunya yang ditekankan pada pekerjaan mental bukan pekerjaan manual. Kemampuan mental yang dimaksudkan disini adalah adanya persyaratan pengetahuan teoritis sebagai instrumen untuk melakukan perbuatan praktis. Faktor yang mempengaruhi pengembangan profesi menurut Suharsaputra (2016) antara lain (1) Memiliki ketrampilan mengajar yang baik, (2) memiliki wawasan luas dan (3) menguasai media pembelajaran.

\section{Faktor Ekstrinsik}

Faktor-faktor intrinsik menurut Robbins (2006) antara lain.

\section{Kebijakan}

Dye (2012) menyebutkan kebijakan sebagai "pilihan", sedangkan, Li (2020) menyebutkan kebijakan sebagai "kekuasaan pengalokasian nilai-nilai untuk masyarakat secara keseluruhan". Menurut Mintrop et al., 2017 kebijakan yaitu ukuran dan kebijakan serta sumber daya.

2. Supervisi

Menurut Sari (2018), Supervisi adalah pelayanan kepada guru yang bertujuan menghasilkan perbaikan, sumber informasi bagi kepala sekolah, guru dan tenaga kependidikan, sebagai fasilitator dan pembimbing yang membantu dalam mengatasi hambatan, sebagai motivator yang cerdas, arif dan efektif, sebagai pengendali mutu penyelenggaraan pendidikan di sekolah melalui mutu peningkatan kurikulum.

3. Gaji

Menurut Hariandja (2002), Gaji merupakan salah satu unsur yang penting yang dapat mempengaruhi kinerja karyawan, sebab gaji adalah alat untuk memenuhi berbagai kebutuhan pegawai, sehingga dengan gaji yang diberikan pegawai akan termotivasi untuk bekerja lebih giat. Faktor-faktor yang mempengaruhi gaji menurut Pasal 2 ayat 1 Peraturan Menteri Ketenagakerjaan No. 1 Tahun 2017 adalah, golongan jabatan, jabatan, masa kerja, pendidikan dan kompetensi.

\section{Motivasi Kerja}

Menurut Hellriegel (2016) motivasi adalah faktor penggerak dalam diri dalam melaksanakan sebuah pekerjaan agar untuk menggapai tujuan yang diharapkan. Kekuatan itu pada dasarnya dipicu oleh aneka kepentingan yaitu (1) keinginan untuk ingin dipenuhi, (2) prilaku, (3) tujuan, dan (4) umpan balik. Sedangkan, Hasibuan (2002) motivasi kerja merupakan memberikan bantuan kepada penggerak yang menciptakan kegembiraan dari pekerjaan seseorang. Motivasi membangun 
antusiasme terhadap kemampuan dalam suatu kegiatan. Dunia pendidikan motivasi menjadi tempat penting di mana peserta didik atau tenaga pendidik menjadi semangat apabila adanya motivasi baik itu datang dari sendiri maupun dari luar dirinya. Teori motivasi berupaya merumuskan agar seseorang dapat memiliki kinerja yang baik Teori tersebut adalah Teori "ERG." Teori ini dirumuskan oleh Aldefer dan merupakan perumusan kembali teori hierarki Maslow. Alderfer (2016) menjelaskan teori itu demikian.

Kekuatan motivasi tenaga kerja untuk bekerja/berkinerja dapat terlihat secara langsung dari caranya bekerja. Menurut Uno dan Lamatenggo (2012) dimensi dan indikator motivasi kerja dapat dikelompokan sebagai berikut:

1. Motivasi internal yaitu tanggung jawab dalam melaksanakan tugas, dengan target yang jelas, memiliki tujuan yang jelas dan menantang, Ada umpan balik atas hasil pekerjaannya dan rasa senang dalam bekerja, Selalu berusaha mengungguli orang lain serta diutamakan prestasi dari apa yang dikerjakannya.

2. Motivasi eksternal yaitu selalu berusaha memenuhi kebutuhan hidup dan kebutuhan kerjanya, senang memperoleh pujian dari apa yang dikerjakannya dan bekerja dengan ingin memperoleh insentif.

\section{Kinerja Guru}

Kinerja guru dideskripsikan sebagai sebuah tugas yang dilaksanakan oleh tenaga pendidik pada suatu waktu tertentu dalam sistem sekolah agar dapat meraih tujuan yang diidealkan oleh lembaga pendidikan tersebut. Kinerja guru merupakan hal yang digapai, pencapaian kerja dimiliki dari pekerjaan tenaga pendidik. Pendidik dalam tugasnya mengajar, ia juga merupakan tenaga pendidik dan pelaksana dalam sekolah. Guru dikatakan sebagai pembuat program, administrasi, fasilitator, dan mengevaluasi peserta didik. Ismail (2010) menyatakan bahwa kinerja guru selalu berhubungan dengan tugas perencanaan pengajaran, pengelolahan proses belajar, dan juga penilaian serta evaluasi. Perencanaan berarti, pendidik dapat membuat jalannya proses belajar setidaknya sesuai konteks. Sedangkan sebagai evaluator berarti guru dapat menilai sendiri. Depertemen Pendidikan Nasional pada Tahun 2003 menguraikan bahwa kinerja guru dalam program pelaksanaan pembelajaran meliputi tiga bagian penting (1) Pra-pembelajaran meliputi mengecek persiapan sebelum belajar dan memberikan apresiasi (2) Kegiatan inti yakni menguasai bahan ajar, memiliki strategi dalam proses belajar, penggunaan media, bahan yang diajarkan atau referensi, evaluasi belajar, dan penggunaan bahasa dalam mengajar (3) Penutup. 


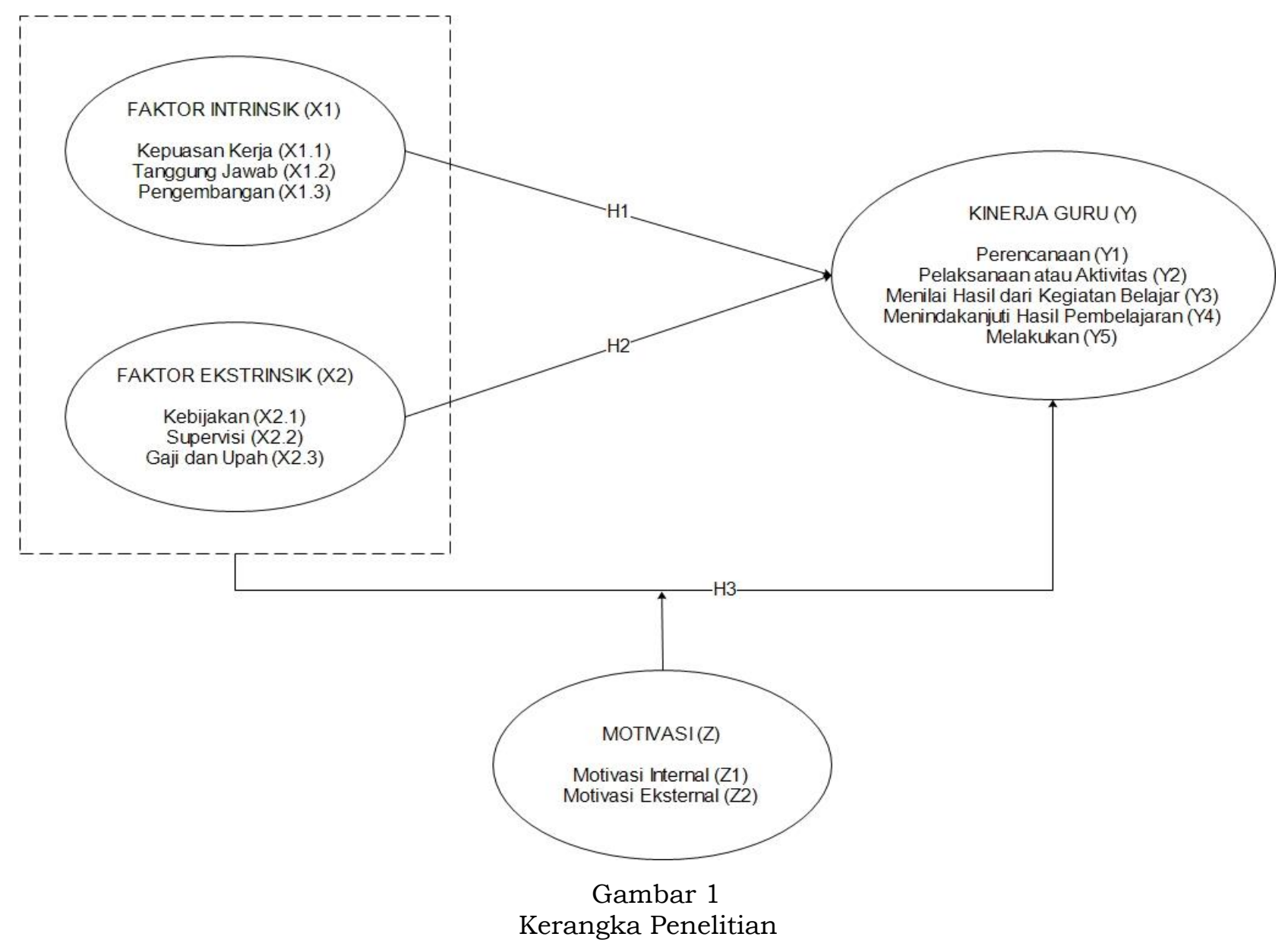

\section{Hipotesis}

Faktor intrinsik menurut Herzberg yang dikutip oleh Siagian (2008) adalah daya dorong yang timbul dari dalam diri masingmasing orang. Adapun indikator dari faktor interinsik adalah kepuasan kerja, Tanggung jawab dan Pengembangan profesi. Hal ini sesuai dengan penelitian Sari (2018) yang meneliti tentang Pengaruh salah satu factor instrinsik. Sehingga dapat disimpulkan hipotesis penelitian pertama.

H1 : Faktor instrinsik mempunyai pengaruh yang positif dan signifikan terhadap kinerja guru.
Faktor ekstrinsik adalah daya dorong yang datang dari luar diri seseorang, terutama dari organisasi tempatnya bekerja. Indikatornya adalah kebijakan, supervisi dan gaji. Penelitian dari Subianto (2016) meneliti tentang Pengaruh dari factor ekstrinsik yaitu, Gaji dan Insentif. Hasil penelitian menunjukkan terdapat pengaruh yang signifikan pemberian insentif terhadap kinerja melalui kepuasan kerja. Maka dapat disimpulkan hipotesis penelitian kedua.

\section{H2 : Faktor ekstrinsik mempunyai pengaruh yang positif dan signifikan terhadap kinerja guru}


Menurut Siagian (2008) Motivasi adalah pendorong mengakibatkan anggota organisasi secara sukarela mengerahkan kemampuan baik itu dalam hal keterampilan maupun waktunya untuk melaksanakan aneka aktivitas. Adapun indicator motivasi dipengaruhi dari kedua factor. Sehingga, akan menghasilkan kinerja yang baik. Hal ini sesuai dengan Ningtyas (2018) meneliti tentang motivasi sebagai Variabel Moderasi terhadap kinerja. Hasil penelitian ini menunjukkan motivasi kerja berpengaruh terhadap kinerja. Menurut Ismail (2010) kinerja guru selalu berhubungan dengan tugas perencanaan, pengajaran dan pengelolaan proses belajar, dan juga penilaian serta evaluasi.Adapun indikator kinerja yaitu perencanaan, pelaksaan atau aktivitas, menilai hasil dari kegiatan belajar, menindaklanjuti hasil pembelajaran

\section{H3 : Faktor instrinsik dan ekstrinsik mempunyai pengaruh positif dan signifikan memoderasi pengaruh Motivasi kerja terhadap kinerja guru.}

\section{METODOLOGI PENELITIAN}

Metode penelitian ini menggunakan desain penelitian kausalitas. Populasinya adalah guru SMP se-Kecamatan Poncokusumo berjumlah 86 guru dengan sampel yaitu guru SMP bersertifikasi, dari 86 guru, terdapat kriteria yang memenuhi syarat yaitu sebanyak 46 orang.
Teknik yang digunakan adalah Purposive sampling. Pengumpulan data pada penelitian ini menggunakan kuesioner. Teknik analisis yang digunakan ada dua yaitu teknik analisis deskriptif dan inferensial. Uji hipotesis dilakukan menggunakan Moderated Regression Analysis (MRA) atau uji interaksi sebagai uji hipotesisnya.

\section{HASIL DAN PEMBAHASAN}

\section{Hasil Penelitian}

Profil demografis dari 46 responden yang berpartisipasi dalam penelitian ini, meliputi umur, jenis kelamin, tingkat pendidikan, dan lama bekerja individu yang ditunjukkan di tabel 1. Dari tabel 1 dapat diketahui bahwa sebagian besar responden berusia 35-39 tahun sebesar 54,3 \%. Hal tersebut dikarenakan pada saat responden telah menyelesaikan pendidikan dan mengabdi menjadi guru, untuk memperoleh sertifikasi guru membutuhkan waktu. Sehingga karakteristik responden berdasarkan umur dominan pada usia 35-39 tahun dan didominasi oleh perempuan.

Dilihat dari segi pendidikan sebagian besar responden guru adalah berpendidikan sarjana dibandingkan pascasarjana, karena salah satu syarat untuk dapat mengajar di pendidikan menengah pertama khusunya adalah sarjana pendidikan. Didominasi antara usia 11 - 15 tahun sebesar 60,9\%. Selanjutnya dalam penelitian diuji seberapa 
besar tingkat skor skala variabel. Faktor Interinsik (X1), Faktor Eksterinsik (X2),
Motivasi (Z) dan Kinerja (Y). Adapun tabel kategori skor terjabar pada tabel 2.

Tabel 1

Profil Responden

\begin{tabular}{llcr} 
& Faktor Strategis & Jumlah & $\begin{array}{c}\text { Persentase } \\
(\%)\end{array}$ \\
\hline Umur & & & \\
\hline $30-34$ & & 25 & 17,4 \\
$35-39$ & & 13 & 54,3 \\
40 tahun keatas & Jumlah & 46 & 28,3 \\
\hline & & & 100,0 \\
\hline Jenis Kelamin & & 17 & 37,0 \\
\hline Laki - Laki & Jumlah & 29 & 63,0 \\
\hline Perempuan & & 46 & 100,0 \\
\hline & & & \\
\hline Pendidikan Terakhir & & 44 & 95,7 \\
\hline Sarjana (S1) & Jumlah & 2 & 4,3 \\
\hline Pasca Sarjana (S2) & & 46 & 100,0 \\
\hline & & & \\
\hline Lama Bekerja & & 6 & 13,0 \\
\hline $5-10$ Tahun & & 28 & 60,9 \\
$11-15$ Tahun & Jumlah & 12 & 26,1 \\
\hline 16 Tahun Keatas & & 46 & 100,0 \\
\hline
\end{tabular}

Sumber : Data diolah, 2019

Tabel 2

Kategori Skala

\begin{tabular}{cc} 
Skala & Kategori \\
$1,00-1,80$ & Sangat Rendah \\
$1,81-2,60$ & Rendah \\
$2,61-3,40$ & Sedang \\
$3,41-4,20$ & Baik \\
$4,21-5,00$ & Sangat Baik \\
\hline Sumber : Arikunto, 2005 &
\end{tabular}

Faktor instrinsik yaitu faktor dalam diri sehingga akan senang terhadap pekerjaannya. Adapun indikator dari faktor intrinsik menurut (Mintrop and Ordenes 2017) adalah kepuasan kerja, Tanggung jawab dan Pengembangan profesi. Tabel 3 menunjukkan distribusi frekuensi faktor interinsik. Pada tabel 3 menunjukkan bahwa sebaran frekuensi Faktor instrinsik memiliki rata-rata sebesar 4,17 , hal ini berarti responden memiliki faktor interinsik yang meliputi kepuasan kerja, Tanggung jawab dan Pengembangan profesi dengan baik. Faktor ekstrinsik yaitu factor yang 
berasal dari luar seseorang. Indikatornya adalah Kebijakan, Supervisi dan Gaji ditunjukkkan pada tabel 4.

Pada tabel 4 menunjukkan bahwa sebaran frekuensi factor ekstrinsik rata-rata sebesar 3,88 yang berarti responden memiliki faktor eksterinsik yang meliputi Kebijakan, Supervisi dan Gaji dengan baik. Adapun indikator motivasi ditunjukkan pada tabel 5. Pada tabel 5 menunjukkan bahwa frekuensi Motivasi rata-rata sebesar 4,11 yang berarti responden memiliki motivasi internal maupun eksternal dengan baik. Motivasi adalah keinginan dalam mencapai tujuan. Berdasarkan hasil penelitian (Tiwari 2020) motivasi guru sangat penting karena dapat meningkatkan keterampilan dan pengetahuan guru selain itu motivasi juga memegang peranan penting yaitu dapat meningkatkan produktivitas guru.

Motivasi juga sebagai proses stimulasi individu untuk mengambil keputusan dan tindakan dalam mencapai tujuan khusus yang diinginkan. Hal tersebut sesuai dengan pendapat (Yoo et al., 2012) yang menyatakan bahwa motivasi sebagai proses psikologis membangkitkan, mengarahkan, dan memelihara perilaku menuju suatu tujuan. Kinerja guru merupakan suatu hasil kerja yang telah diberikan kepadanya untuk mencapai tujuan.

Tabel 3

Distribusi Frekuensi Faktor Interinsik ( X1 )

\begin{tabular}{|c|c|c|c|c|c|c|c|c|c|c|c|c|}
\hline \multirow{3}{*}{ Skala } & \multicolumn{10}{|c|}{ Frekuensi } & \multirow{3}{*}{$\mathbf{N}$} & \multirow{2}{*}{$\begin{array}{l}\text { Rata - } \\
\text { Rata }\end{array}$} \\
\hline & \multicolumn{2}{|c|}{1} & \multicolumn{2}{|c|}{2} & \multicolumn{2}{|c|}{3} & \multicolumn{2}{|c|}{4} & \multicolumn{2}{|c|}{5} & & \\
\hline & $\mathrm{f}$ & $\%$ & $\mathrm{f}$ & $\%$ & $\mathrm{f}$ & $\%$ & $\mathrm{f}$ & $\%$ & $\mathrm{f}$ & $\%$ & & \\
\hline $\mathrm{X} 1.1$ & - & 0 & - & 0 & 4 & 8,7 & 32 & 69,6 & 10 & 21,7 & 46 & 4,13 \\
\hline $\mathrm{X} 1.2$ & - & 0 & - & 0 & 3 & 6,5 & 28 & 60,9 & 15 & 32,6 & 46 & 4,26 \\
\hline $\mathrm{X} 1.3$ & - & 0 & - & 0 & 7 & 15,2 & 26 & 56,5 & 13 & 28,3 & 46 & 4,13 \\
\hline $\mathrm{X} 1.4$ & - & 0 & - & 0 & 5 & 10,9 & 28 & 60,9 & 13 & 28,3 & 46 & 4,17 \\
\hline X1.5 & - & 0 & - & 0 & 4 & 8,7 & 26 & 56,5 & 16 & 34,8 & 46 & 4,26 \\
\hline X1.6 & - & 0 & - & 0 & 6 & 13 & 27 & 58,7 & 13 & 28,3 & 46 & 4,15 \\
\hline $\mathrm{X} 1.7$ & - & 0 & - & 0 & 6 & 13 & 28 & 60,9 & 12 & 26,1 & 46 & 4,13 \\
\hline $\mathrm{X} 1.8$ & - & 0 & - & 0 & 2 & 4,3 & 32 & 69,6 & 12 & 26,1 & 46 & 4,21 \\
\hline X1.9 & - & 0 & - & 0 & 5 & 10,9 & 29 & 63 & 12 & 26,1 & 46 & 4,15 \\
\hline $\mathrm{X} 1.10$ & - & 0 & - & 0 & 3 & 6,5 & 30 & 65,2 & 13 & 28,3 & 46 & 4,21 \\
\hline $\mathrm{X} 1.11$ & - & 0 & - & 0 & 6 & 13 & 28 & 60,9 & 12 & 26,1 & 46 & 4,13 \\
\hline $\mathrm{X} 1.12$ & - & 0 & - & 0 & 9 & 19,6 & 30 & 65,2 & 7 & 15,2 & 46 & 3,95 \\
\hline $\mathrm{X} 1.13$ & - & 0 & - & 0 & 3 & 6,5 & 28 & 60,9 & 15 & 32,6 & 46 & 4,26 \\
\hline $\mathrm{X} 1.14$ & - & 0 & - & 0 & 5 & 10,9 & 28 & 60,9 & 13 & 28,3 & 46 & 4,17 \\
\hline $\mathrm{X} 1.15$ & - & 0 & - & 0 & 6 & 13 & 26 & 56,5 & 14 & 30,4 & 46 & 4,17 \\
\hline
\end{tabular}

Sumber : Data diolah, 2019 
Tabel 4

Distribusi Frekuensi Faktor ekstrinsik ( X2)

\begin{tabular}{|c|c|c|c|c|c|c|c|c|c|c|c|c|}
\hline \multirow{3}{*}{ Skala } & \multicolumn{10}{|c|}{ Frekuensi } & \multirow{3}{*}{$\mathbf{N}$} & \multirow{3}{*}{$\begin{array}{l}\text { Rata - } \\
\text { Rata }\end{array}$} \\
\hline & \multicolumn{2}{|c|}{1} & \multicolumn{2}{|c|}{2} & \multicolumn{2}{|c|}{3} & \multicolumn{2}{|c|}{4} & \multicolumn{2}{|c|}{5} & & \\
\hline & $\mathrm{f}$ & $\%$ & f & $\%$ & f & $\%$ & f & $\%$ & f & $\%$ & & \\
\hline X2.1 & - & 0 & 2 & 4,3 & 10 & 21,7 & 30 & 65,2 & 4 & 8,7 & 46 & 3,78 \\
\hline X2.2 & - & 0 & - & 0 & 8 & 17,4 & 30 & 65,2 & 8 & 17,4 & 46 & 4,00 \\
\hline X2.3 & - & 0 & - & 0 & 15 & 32,6 & 26 & 56,5 & 5 & 10,9 & 46 & 3,78 \\
\hline X2.4 & - & 0 & - & 0 & 17 & 37,0 & 26 & 56,5 & 3 & 6,5 & 46 & 3,69 \\
\hline X2.5 & - & 0 & 1 & 2,2 & 13 & 28,3 & 28 & 60,9 & 4 & 8,7 & 46 & 3,76 \\
\hline $\mathrm{X} 2.6$ & - & 0 & - & 0 & 15 & 32,6 & 24 & 52,2 & 7 & 15,2 & 46 & 3,82 \\
\hline $\mathrm{X} 2.7$ & - & 0 & - & 0 & 7 & 15,2 & 25 & 54,3 & 14 & 30,4 & 46 & 4,15 \\
\hline X2.8 & - & 0 & - & 0 & 11 & 23,9 & 27 & 58,7 & 8 & 17,4 & 46 & 3,93 \\
\hline X2.9 & - & 0 & 2 & 4,3 & 6 & 13,0 & 28 & 60,9 & 10 & 31,7 & 46 & 4,00 \\
\hline $\mathrm{X} 2.10$ & - & 0 & - & 0 & 7 & 15,2 & 35 & 76,1 & 4 & 8,7 & 46 & 3,93 \\
\hline $\mathrm{X} 2.11$ & - & 0 & 2 & 4,3 & 6 & 13,0 & 35 & 76,1 & 3 & 6,5 & 46 & 3,84 \\
\hline \multicolumn{12}{|c|}{ Rata - Rata } & 3,88 \\
\hline
\end{tabular}

Sumber : Data diolah, 2019

Tabel 5

Distribusi Frekuensi Motivasi ( $Z$ )

\begin{tabular}{|c|c|c|c|c|c|c|c|c|c|c|c|c|}
\hline \multirow{3}{*}{ Skala } & \multicolumn{10}{|c|}{ Frekuensi } & \multirow{3}{*}{$\mathbf{N}$} & \multirow{3}{*}{$\begin{array}{c}\text { Rata - } \\
\text { Rata }\end{array}$} \\
\hline & \multicolumn{2}{|c|}{1} & \multicolumn{2}{|c|}{2} & \multicolumn{2}{|c|}{3} & \multicolumn{2}{|c|}{4} & \multicolumn{2}{|c|}{5} & & \\
\hline & f & $\%$ & $\mathrm{f}$ & $\%$ & $\mathrm{f}$ & $\%$ & $\mathrm{f}$ & $\%$ & $\mathrm{f}$ & $\%$ & & \\
\hline Z.1 & - & 0 & - & 0 & 4 & 8,7 & 27 & 58,7 & 15 & 32,6 & 46 & 4,23 \\
\hline Z.2 & - & 0 & - & 0 & 7 & 15,2 & 19 & 41,3 & 20 & 43,5 & 46 & 4,28 \\
\hline Z.3 & - & 0 & - & 0 & 10 & 21,7 & 27 & 58,7 & 9 & 19,6 & 46 & 3,97 \\
\hline$Z .4$ & - & 0 & - & 0 & 12 & 26,1 & 23 & 50,0 & 11 & 23,9 & 46 & 3,97 \\
\hline$Z .5$ & - & 0 & - & 0 & 4 & 8,7 & 23 & 50,0 & 19 & 41,3 & 46 & 4,32 \\
\hline$Z .6$ & - & 0 & - & 0 & 7 & 15,2 & 25 & 54,3 & 14 & 30,4 & 46 & 4,15 \\
\hline Z.7 & - & 0 & - & 0 & 11 & 23,9 & 24 & 52,2 & 11 & 23,9 & 46 & 4,00 \\
\hline Z.8 & - & 0 & - & 0 & 6 & 13 & 29 & 63,0 & 11 & 23,9 & 46 & 4,10 \\
\hline Z.9 & - & 0 & - & 0 & 9 & 19,6 & 22 & 47,8 & 15 & 32,6 & 46 & 4,13 \\
\hline Z.10 & - & 0 & - & 0 & 7 & 15,2 & 33 & 71,7 & 6 & 13,0 & 46 & 3,97 \\
\hline & & & & & $\mathbf{R a}$ & - Rata & & & & & & 4,11 \\
\hline
\end{tabular}

Sumber : Data diolah, 2019

Hasil uji heterokedastisitas faktor interinsik dan faktor eksterinsik terhadap kinerja menunjukkan tidak terjadi heterokedastisitas, hal ini dibuktikan pada gambar 2 menunjukkan bahwa titik-titik yang teratur. Hasil uji heterokedastisitas faktor interinsik dan faktor eksterinsik dimoderasi motivasi terhadap kinerja menunjukkan tidak terjadi heterokedastisitas, hal ini dibuktikan pada gambar 3 yang menunjukkan bahwa titiktitik yang ada teratur. Sehingga terjadi heteroskodesitas.

Berdasarkan hasil penelitian (Li and Park 2019) menyatakan bahwa kurangnya motivasi guru menyebabkan prestasi akademik siswa yang rendah. Temuan lain juga mengungkapkan bahwa kurangnya 
dukungan juga membuat guru menjadi kurang termotivasi terhadap pekerjaan. (Abdulrasheed et al. 2016) menyatakan bahwa dukungan berupa memberikan reward atau insentif memiliki efek positif untuk memotivasi guru atas pekerjaannya.

Dilihat dari hasil distribusi frekuensi variabel sebesar 4,17 yang menunjukkan bahwa rata-rata Guru di SMP se-kecamatan Poncokusumo memiliki faktor intrinsik dengan baik. Faktor Intrinsik merupakan faktor yang memotivasi diri individu tersebut sehingga dikenal sebagai faktor motivasional. Faktor ini merupakan sumber motivasi terkuat dalam diri karyawan karena dapat mendorongnya untuk memberikan seluruh kemampuannya dalam bekerja.

Faktor Intrinsik yaitu kepuasan kerja, tanggung jawab dan pengembangan profesi. Apabila dilihat Faktor intrinsik dari segi kepuasan kerja yaitu guru di SMP sekecamatan Poncokusumo menyenangi dan mencintai pekerjaannya, memiliki moral kerja positif, disiplin dalam bekerja dan mampu berprestasi kerja. Guru di SMP sekecamatan Poncokusumo pun mempunyai tanggungjawab secara intelektual, profesi/ pendidikan, sosial, moral dan spiritual serta memiliki tanggung jawab pribadi.

Dari segi Pengembangan profesi ratarata guru di SMP se kecamatan Poncokusumo memiliki ketrampilan mengajar yang baik dan menguasai media pembelajaran bagi siswanya. Dengan adanya faktor intrinsik baik di SMP sekecamatan Poncokusumo, maka kinerja guru akan meningkat sehingga siswa merasa semangat untuk belajar.

Hasil perhitungan pada pengujian dan df 46 , diketahui nilai t-test untuk variabel X2 adalah 2,025 > 2,0154 dan tingkat signifikansi 0,049<0,05 . Dengan demikian hipotesis yang menyatakan bahwa ada pengaruh antara Faktor Ekstrinsik terhadap Kinerja dapat diterima (H2 diterima). Distribusi frekuensi variabel faktor ekstrinsik rata-rata sebesar 3,88 yang menunjukkan bahwa guru di SMP sekecamatan Poncokusumo memiliki faktor eksterinsik yang baik.

Faktor ekstrinsik merupakan dari luar individu. Faktor ekstrinsik tersebut antara lain Kebijakan, Supervisi dan Gaji. Adanya kebijakan yang baik di tempat kerja seperti aturan yang tidak memberatkan, pengamatan dan evaluasi yang baik dari instansi serta gaji yang cukup dalam memenuhi kebutuhan maka hal tersebut dapat meningkatkan kinerja guru.

Diketahui bahwa adanya peningkatan nilai $\mathrm{R}$ Square antara persamaan pertama dengan persamaan kedua dari 53,5 \% menjadi 53,6 \%. Artinya bahwa adanya motivasi maka akan memperkuat hubungan antara Faktor interinsik dan faktor eksterinsik terhadap kinerja guru di SMP se-kecamatan Poncokusumo. 


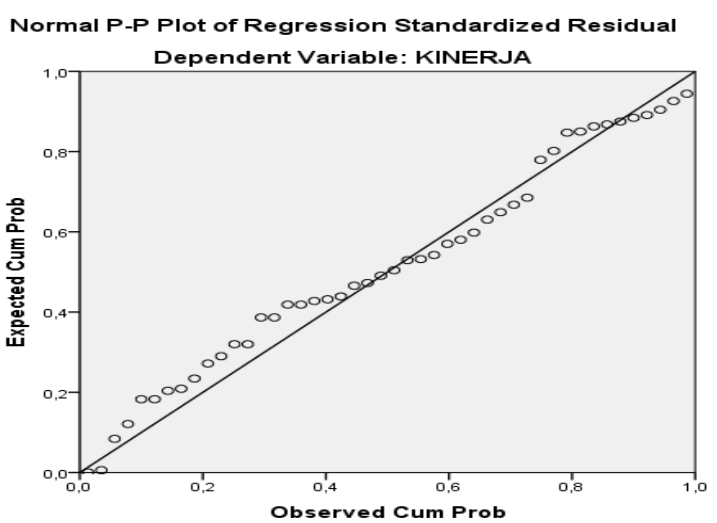

Charts

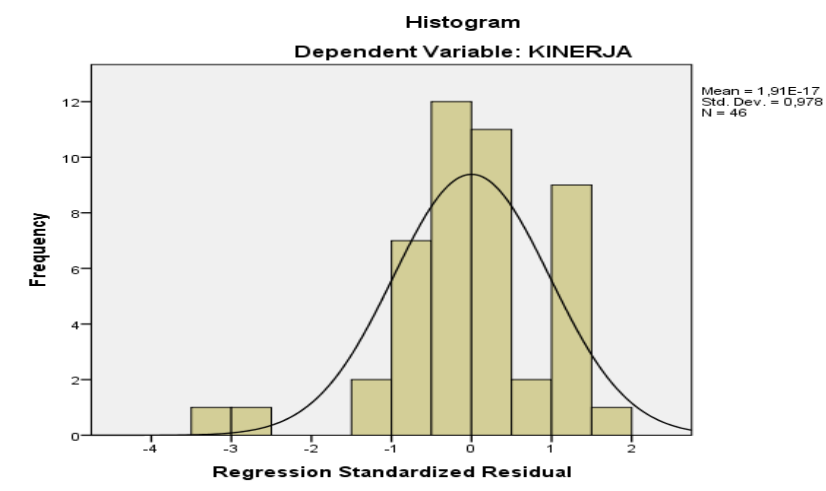

Sumber : Data Diolah (2020)

Gambar 2. Faktor Interinsik dan Faktor Eksterinsik Terhadap Kinerja

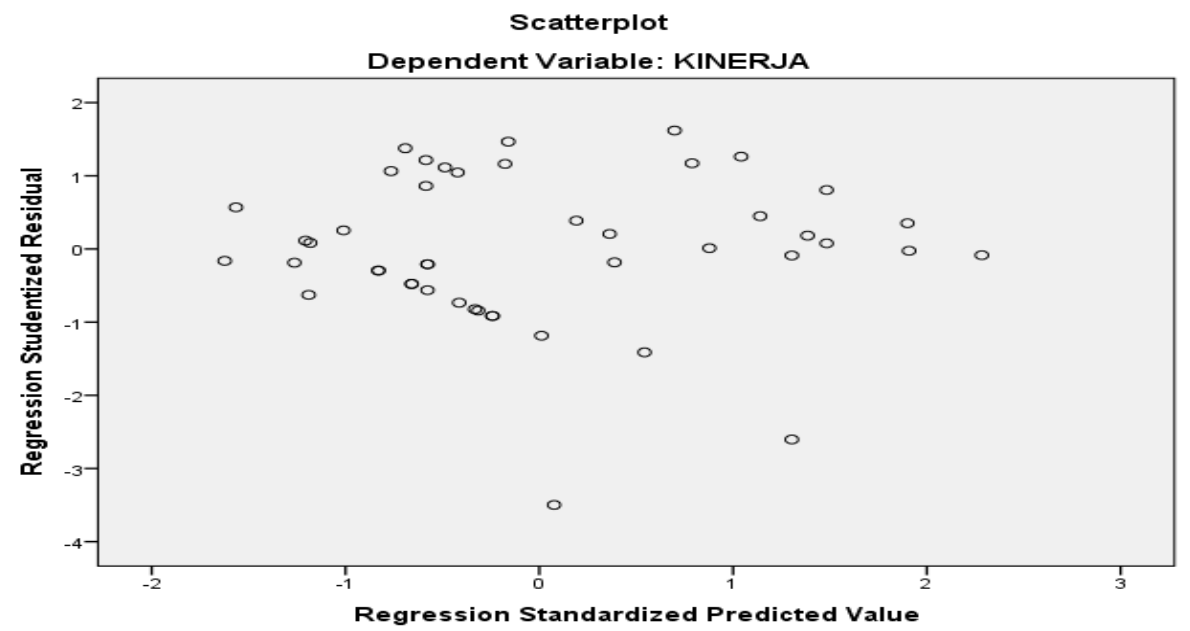

Sumber : Data Diolah (2020)

Gambar 3. Uji Heterokedastisitas Faktor Interinsik dan Faktor Eksterinsik Terhadap Kinerja

Scatterplot

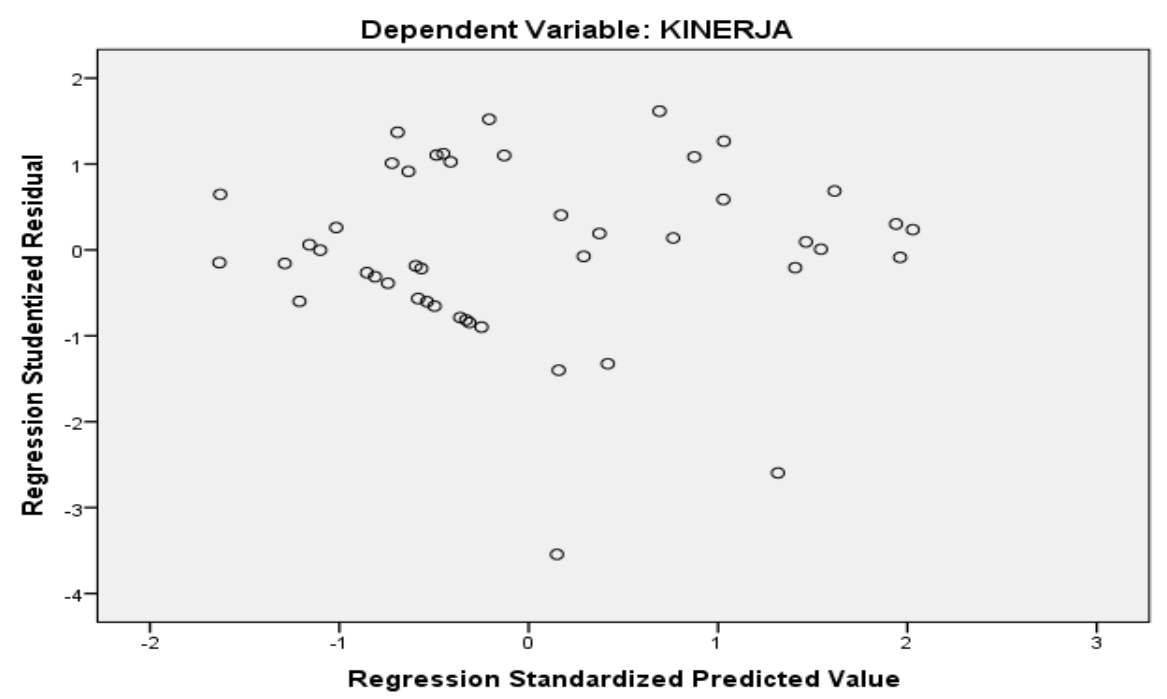

Sumber : Data Diolah (2020)

Gambar 4. Uji Heterokedastisitas Faktor Interinsik dan Faktor Eksterinsik Dimoderasi Motivasi Terhadap Kinerja 


\section{Pembahasan}

Pengujian pada pengaruh Faktor Intrinsik tersebut dilihat dari t-hitung 6,828 > t-tabel 2,0154 dengan tingkat signifikansi sebesar 0,000. Dilihat dari hasil distribusi frekuensi variabel yaitu sebesar 4,17 yang menunjukkan bahwa rata-rata Guru di SMP se-kecamatan Poncokusumo memiliki faktor intrinsik dengan baik. Faktor ini merupakan sumber motivasi terkuat dalam diri karyawan karena dapat mendorongnya untuk memberikan seluruh kemampuan dalam bekerja.

Faktor Intrinsik disini adalah kepuasan kerja, tanggung jawab dan pengembangan profesi. Bila dilihat Faktor intrinsik dari segi kepuasan kerja yaitu guru di SMP sekecamatan Poncokusumo menyenangi dan mencintai pekerjaan mereka, memiliki moral kerja positif, disiplin dalam bekerja dan mampu berprestasi kerja. Penelitian yang dilakukan oleh Sari (2018) tentang Pengaruh Kepuasan Kerja Terhadap Kinerja Karyawan Dengan Organizational Citizenship Behavior Sebagai Variabel Intervening Di Pabrik Gula Mojopanggung. Hasil analisis menyatakan bahwa kepuasan kerja Guru di SMP se-kecamatan Poncokusumo mempunyai tanggungjawab secara intelektual, profesi/pendidikan, sosial, moral dan spiritual serta memiliki tanggung jawab pribadi. Hasil analisis bahwa tanggung jawab sosial perusahaan dan komitmen organisasi mampu berpengaruh terhadap kinerja. Dari segi Pengembangan profesi rata-rata guru di SMP se-kecamatan Poncokusumo memiliki ketrampilan mengajar yang baik dan menguasai media pembelajaran bagi siswanya. Adanya faktor intrinsik baik di SMP se-kecamatan Poncokusumo, maka kinerja guru akan meningkat sehingga siswa merasa semangat untuk belajar.Hasil penelitian dari Kabella (2016) menunjukkan bahwa profesionalisme memiliki peran penting bagi peningkatan kinerja pegawai.

Pada pengaruh Faktor Ekstrinsik terhadap Kinerja menunjukkan bahwa Faktor Ekstrinsik dilihat dari t-hitung 2,025 $>$ t-tabel 2,0154 dengan tingkat signifikansi sebesar 0,049. Distribusi frekuensi variabel faktor ekstrinsik rata-rata sebesar 3,88 yang menunjukkan bahwa guru di SMP sekecamatan Poncokusumo memiliki faktor eksterinsik dengan baik. Faktor ekstrinsik tersebut antara lain Kebijakan, Supervisi dan Gaji. Hasil ini sesuai dengan penelitian dari Subianto (2016) meneliti tentang Pengaruh Gaji Dan Insentif Terhadap Kinerja. Hasil penelitian menunjukkan terdapat pengaruh pemberian insentif terhadap kinerja melalui kepuasan kerja. Faktor Intrinsik dan Eksterinsik memoderasi pengaruh Motivasi Terhadap Kinerja guru Hasil pengujian menunjukkan bahwa Faktor Intrinsik dan Eksterinsik memoderasi pengaruh dari Motivasi Terhadap Kinerja guru. 
Faktor interinsik dan faktor eksterinsik merupakan faktor yang dapat mempengaruhi kinerja guru. Di penelitian ini motivasi memperkuat hubungan antara faktor intrinsik dan faktor ekstrinsik terhadap kinerja guru. Sehingga, Jika Motivasi kerja meningkat maka akan berpengaruh terhadap kinerja guru SMP sekecamatan Poncokusumo. Hasil dari Ningtyas (2018) meneliti tentang Pengaruh Motivasi Kerja Terhadap Kinerja. Hasil penelitian ini menunjukkan bahwa motivasi kerja berpengaruh terhadap kinerja karyawan

\section{Hasil pengujian hipotesis}

Pengujian pada pengaruh Faktor dilihat dari t-hitung 6,828 > t-tabel 2,0154 dengan tingkat signifikansi sebesar 0,000. Dari hasil distribusi frekuensi variabel yaitu sebesar 4,17 yang menunjukkan bahwa rata-rata Guru di SMP se-kecamatan Poncokusumo memiliki faktor intrinsik dengan baik. Pengujian pada pengaruh Faktor Ekstrinsik dari t-hitung 2,025 > ttabel 2,0154 dengan tingkat signifikansi sebesar 0,049. Distribusi frekuensi variabel faktor ekstrinsik rata-rata sebesar 3,88 yang menunjukkan bahwa guru di SMP sekecamatan Poncokusumo memiliki faktor eksterinsik dengan baik. Hasil pengujian menunjukkan bahwa Faktor Intrinsik dan Faktor Eksterinsik Dimoderasi Motivasi Terhadap Kinerja. Motivasi dikatakan memoderasi terhadap kinerja jika nilai kedua R Square menurun atau meningkat. Hasil R Square regresi pertama yaitu sebesar 0,535 atau 53,5 \% sedangkan, persamaan yang kedua yaitu sebesar 0,536 atau 53,6 \%. Dari kedua persamaan diketahui bahwa adanya peningkatan nilai $\mathrm{R}$ Square antara persamaan pertama dengan persamaan kedua dari 53,5 \% menjadi 53,6 \%. Artinya adanya motivasi maka akan memperkuat hubungan antara faktor intrinsik dan faktor ekstrinsik terhadap kinerja.

\section{KESIMPULAN}

Hasil dari pengujian dan analisa di penelitian ini menunjukan Faktor Intrinsik merupakan faktor yang dari diri individu tersebut sehingga dikenaL sebagai faktor motivasional. Faktor Intrinsik adalah kepuasan kerja, tanggung jawab dan pengembangan profesi. Adanya faktor intrinsik yang baik dimiliki oleh guru di SMP se-kecamatan Poncokusumo, maka kinerja guru dapat meningkat dan siswa merasa semangat untuk belajar. Sehingga Faktor instrinsik berpengaruh signifikan terhadap kinerja guru di SMP se-kecamatan Poncokusumo.

Faktor ekstrinsik merupakan faktor berasal dari luar individu. Faktor ekstrinsik yaitu Kebijakan, Supervisi dan Gaji. Adanya kebijakan yang baik di tempat kerja seperti aturan yang tidak memberatkan, pengamatan dan evaluasi yang baik dari 
instansi serta gaji yang cukup dalam memenuhi kebutuhan maka hal tersebut dapat meningkatkan kinerja guru. Sehingga Faktor ekstrinsik berpengaruh signifikan terhadap kinerja.

Motivasi merupakan kegiatan tertentu guna mencapai suatu tujuan. Motivasi memperkuat hubungan antara faktor interinsik dan faktor eksterinsik pada kinerja guru. Sehingga, jika motivasi kerja baik maka berpengaruh terhadap peningkatan kinerja guru.

\section{IMPLIKASI PENELITIAN}

Penelitian ini dapat memberikan rujukan dalam mengidentifikasi pengaruh dari factor instrinsik dan ekstrinsik serta motivasi yang dapat memperkuat kedua factor tersebut baik instrinsik dan ekstrinsik sehingga kinerja dapat menjadi meningkat.

\section{ACKNOWLEDGEMENT}

Penulis berterima kasih kepada Kepala Sekolah dan guru- guru SMP se-kecamatan Poncokusumo atas dukungan dalam pengambilan data dan berjalan baik.

\section{DAFTAR PUSTAKA}

Abdulrasheed, Olowoselu, Maryam Adamu Nyako, Aishatu Salihu Bello, and Fatima Joda. 2016. "Analysis of Lecturers on Factors Affecting Quality of Training in Teacher Education."

Alderfer, C. 2016. Pembelajaran Peranan Motivasi dan Kemampuan Awal dalam Kegiatan Pembelajaran. Jakarta: Delia Press

Arikunto, Suharsimi. 2005. Metedologi Penelitian. Yogyakarta: Bina Aksara

Cholil, Muhammad. 2014. Pengaruh Kepemimpinan Kepala Sekolah dan Motivasi Kerja Terhadap Kinerja GuruDi SMP Muhammadiyah Ngawi. Media Prestasi Jurnal Imiah STKIP PGRI Ngawi. Vol 12: 92-101.

Danim, Sudarwan. 2002. Inovasi Pendidikan dalam Upaya Peningkatan Profesionalisme Tenaga Kependidikan. Bandung: CV Pustaka Setia.

Deci, Edward L., and Richard M. Ryan. 2008. "Self-Determination Theory: A Macrotheory of Human Motivation, Development, and Health." Canadian Psychology/Psychologie Canadienne 49(3):182-85. doi: 10.1037/a0012801.

Decreuse, Bruno, and Pierre Granier. 2013. "Unemployment Benefits, Job Protection, and the Nature of Educational Investment." Labour Economics 10.

Dye, Thomas R. 2012. Understanding Public Policy. USA : Prentice-Hall, INC., Englewood Cliffs, NJ.

Gunarsa, D.Singgih. 2008. Psikologi Olah Raga Prestasi. Jakarta : Gunung Mulia

Hamid, Djamhur. 2017. Pengaruh Motivasi dan Kemampuan Kerja Terhadap Kinerja Karyawan. Jurnal Administrasi Bisnis. Volume 1 Nomor 1. 
Hariandja, Marihot Tua Efendi. 2002. Manajemen Sumber Daya Manusia. Jakarta: PT.Grasindo

Hasibuan, Malayu S P.2002. Manajemen Sumber Daya Manusia (edisi revisi). Jakarta : Bumi Aksara.

Hellriegel. 2016. Organizational Behaviour. Sebastopol : Alex Media Computindo.

Hernando, Hendrick. 2016. Determinan Motivasi Kerja : Tinjauan Faktor Instrinsik dan Ekstrinsik di PT. Kaltim Medika Utama Medika. Jurnal Media Studi Ekonomi. Volume 1 Nomor 1.

Ismail, Mohamad. 2010. Manajemen Operasional Sekolah. Bandung: PT Remaja Rosdakarya. Journal Administrasi Bisnis. Volume 4 Nomor 3 : 698-712.

Kabella, Dina Anindya. 2016. Analisi Tentang Pengaruh Profesionalisme Birokrasi Terhadap Kinerja Pegawai

Li, Nanyun, and Hyesook Park. 2019. "The Relationships of Self-Directed Learning Readiness and Motivation with the English Proficiency of Korean EFL Learners." 29

Li, Ping. 2020. "Factors Influencing Learning Effectiveness of Educational Travel_A Case Study in China." Journal of Hospitality and Tourism Management 12.

Luthan, Fred. 2011. Perilaku Organisasi. Cetakan Keempat. Yogyakarta: Penerbit Andi Offset.

Mas'ud. 2017. Pengaruh Kompetensi Kepala Sekolah, Motivasi dan Kompetensi Guru Terhadap Kinerja Guru serta Implikasinya pada Kompetensi Lulusan. Kontigensi. Volume 5. No.2: 122-131.

Mintrop, Rick, and Miguel Ordenes. 2017. "Teacher Work Motivation in the Era of Extrinsic Incentives: Performance Goals and pro-Social Commitments in the Service of Equity." Education Policy Analysis Archives 25:44. doi: 10.14507/epaa.25.2482.

Mulyana, E. 2006. Menjadi guru profesional. PT Rosda Karya, Bandung

Muskanan, Karel. 2014. Faktor Instrinsik, Faktor Ekstrinsik dan Motivasi Berprestasi. Jurnal Kebijakan Publik. Volume 5 Nomor 1 : 55-60.

Ningtyas, Nurcahyati Dwi Ayu. 2018. Pengaruh Motivasi Kerja Terhadap Kinerja Karawan Dengan Motivasi Islam Sebagai Variabel Moderasi. Jurnal Ekonomi Syariah. Volume 3 Nomor 2.

Robbins, Stephen 2006. Perilaku Organisasi (Organisasi Behaviour). Jakarta : PT. Prehalindo.

Sari, Oxy Rindiantika. 2018. Pengaruh Kepuasan Kerja Terhadap Kinerja Karyawan Dengan Organizational Citizenship Behaviour Sebagai Variabel Intervening. Jurnal Administrasi Bisnis. Volume 64 Nomor 1.

Sedarmayanti. 2009. Sumber Daya Manusia Dan Produktivitas Kerja. Bandung : Penerbit Mandar Madu 
Shaw, George Bernard. 2018. Persaingan Masyrakat. Jakarta : Rajawali press

Siagian, P. Sondang. 2008. Manajemen Sumber Daya Manusia. Jakarta: Bumi Aksara

Subianto, Marianus. 2016. Pengaruh Gaji Dan Insetif Terhadap Kinerja Karyawan.

Suharsaputra, Uhar. 2016. Etika dan Profesi Kependidikan. Jogjakarta: Arruz.

Tiwari, Pragya. 2020. "Effect Of Extrinsic And Intrinsic Motivation On Teachers Job Performance." 4.

Uno, H. B., \& Lamatenggo, N. 2012. Teori kinerja dan pengukurannya. Jakarta: Bumi Aksara. 10.1109/ICOVET50258.2020.9230222.'

Yamin, Martini. 2006. Sertifikasi Profesi Keguruan di Indonesia. Jakarta: Gaung. Persada, hal 71. 1.

Yoo, Sun Joo, Seung-hyun Han, and Wenhao Huang. 2012. "The Roles of Intrinsic Motivators and Extrinsic Motivators in Promoting E-Learning in the Workplace: A Case from South Korea." Computers in Human Behavior 28(3):942-50. doi: 10.1016/j.chb.2011.12.015. 